\title{
Histomorphometry evaluation of bone anabolism promoted by prostaglandin E1 and its relation to hypercalcemia
}

\author{
Francisco H. Velásquez-Forero ${ }^{1 *}$ and Pedro F. Valencia-Mayoral ${ }^{2}$ \\ ${ }^{1}$ Unidad de Investigación y Diagnóstico en Nefrología y Metabolismo Mineral Óseo; 2 Dirección de Planeación. Hospital Infantil de México Federico \\ Gómez, Mexico City, Mexico
}

\begin{abstract}
Background: At present, parathyroid hormone is the only existing anabolic bone therapy but produces hypercalcemia. Prostaglandin E1 ( $\left.P G E_{1}\right)$ has been suggested as a bone anabolic agent that allows bone modeling formation without producing hypercalcemia. This study aimed to corroborate these $P G E_{1}$ properties. Methods: For 22 days, rabbits $(n=30)$ were divided into three groups ( $n=10$ each group) and received intravenous solutions: vehicle (control group), palate disjunction + vehicle (sham group), and palate disjunction + $50 \mu \mathrm{g}$ of $P G E_{1}\left(P G E_{1}\right.$ group). On days 1, 3, and 22, palatine suture $X$-rays were taken. On day 22, bone formation markers were analyzed, and the rabbits were sacrificed. Bone palate undecalcified samples were processed. Histomorphometry software was used to analyze bone parameters, and the mineralization front was stained with toluidine blue. Scalloped lines reflect remodeling-based bone formation (RBF), and smooth lines reflect modeling-based formation (MBF). Results: X-rays showed more significant palatal disjunction in the $P G E_{1}$ group; this group exhibited significant calcitriol serum increments. Hypercalciuria was observed in the $P G E_{1}$ group, and resorption markers ( $N$-telopeptides) remained stable. Sutural bones in the $P G E_{1}$ group exhibited significant anabolism in structural parameters. RBF was $20 \%$, and MBF was $6 \%$ in the sham group; in the $P G E_{1}$ group, RBF was $8.6 \%$, and MBF was $17 \%$. In the $P G E_{1}$ group, mineralization was significantly accelerated, but resorption remained stable. Conclusions: This model suggests that $P G E_{1}$ favors palate disjunction, calcitriol synthesis, and shortens the mineralization. Therefore, $P G E_{1}$ is an important bone anabolic molecule predominantly of modeling-based form and no hypercalcemia.
\end{abstract}

Keywords: Prostaglandin E1 bone anabolism. Calcitriol increments. Anabolism without hypercalcemia. Modeling-based bone formation. Remodeling-based bone formation and shortening bone mineralization.

\section{Evaluación histomorfométrica del anabolismo óseo en la reparación promovida por la prostaglandina E1 y su relación con la hipercalcemia}

\section{Resumen}

Introducción: La hormona paratiroidea es la única molécula anabólica ósea, pero ocasiona hipercalcemia. La prostaglandina E1 ( $\left.P G E_{1}\right)$ sugiere ser un anabólico óseo con formación por modelación predominante y generalmente no ocasiona hipercalcemia. El objetivo de este estudio fue corroborar estas propiedades de la PGE divididos en tres grupos ( $n=10$ cada grupo) recibieron una solución por vía intravenosa: vehículo (grupo control), disyunción palatina más vehículo (grupo sham) y disyunción palatina más $50 \mu \mathrm{g}$ de $P G E_{1}$ (grupo $P G E_{1}$ ). A los días 1, 3 y 22 se obtu-

\section{Correspondence:}

*Francisco Hernany Velásquez Forero

E-mail: fcovelfor@gmail.com
Date of reception: 12-06-2019

Date of acceptance: 19-02-2020

DOI: 10.24875/BMHIM.20000080
Available online: 02-06-2021

Bol Med Hosp Infant Mex. 2021;78(4):293-300

www.bmhim.com (http://creativecommons.org/licenses/by-nc-nd/4.0/). 
vieron radiografías de la sutura palatina. En el día 22 se analizaron los marcadores bioquímicos de formación ósea y se sacrificó a los conejos. Las suturas y los huesos suturales se procesaron sin descalcificar. La evaluación histomorfométrica fue digitalizada y el frente de mineralización ósea se tiñó con azul de toluidina. Las líneas irregulares reflejan resorción (remodelación) y las líneas rectas no resorción (modelación). Resultados: Radiográficamente, la disyunción palatina fue mayor en el grupo $P G E_{+}$Este grupo mostró una hipercalcitonemia significativa, pero la calcemia y los marcadores resortivos

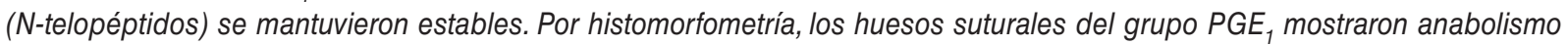
significativo en parámetros estructurales. En el grupo sham, la remodelación ósea fue del $20 \%$ y la modelación fue del 6\%; en el grupo $P G E_{1}$, la remodelación fue del $8.6 \%$ y la modelación fue del $17 \%$. En este mismo grupo, la mineralización fue significativamente acelerada, pero la resorción se mantuvo igual. Conclusiones: Este modelo sugiere que la PGE favorece la disyunción palatina y el aumento del calcitriol, y acelera la mineralización y el anabolismo óseo por modelación predominante sin hipercalcemia.

Palabras clave: Anabolismo óseo prostaglandina E1 (PGE1). Aumento del calcitriol. Anabolismo óseo sin hipercalcemia. Formación ósea por remodelación. Aceleración de la mineralización ósea.

\section{Introduction}

Prostanoids (PGs) are derived from fatty acids of cell membranes and released by phospholipase A2 $\left(\mathrm{PLA}_{2}\right)^{1}$. $P G$ are classified into three series. Series 1 components are synthesized from homo- $\gamma$-linoleic acid, which is the origin of prostaglandin $\mathrm{E}_{1}\left(\mathrm{PGE}_{1}\right)^{2}$.

For more than one decade, anabolic therapy for osteopenia has generated great enthusiasm. Four forms of the parathyroid hormone (PTH), 1-34, 1-84, $1-36$, and abaloparatide, are currently the only anabolic bone therapy. PTH increases bone formation and bone resorption, causing hypercalcemia ${ }^{3,4}$. An ideal anabolic bone treatment would optimize bone formation with minimal change in resorption and no hypercalcemia ${ }^{3,5}$. Our objective was to investigate by biochemical and histomorphometry studies, including remodeling-based bone formation (RBF) and modeling bone formation (MBF), if $P G E_{1}$ might be a suitable bone anabolic agent that could be used in diseases such as osteoporosis, maxillary deficiency, and others.

\section{Methods}

This study was conducted following institutional, national, and international norms ${ }^{6,7}$. Thirty 3-month-old New Zealand male rabbits of approximately $3 \mathrm{~kg}$ of body weight were divided randomly into three groups ( $n=10$ ): control group (with no palate disjunction + vehicle); sham group (with palate disjunction + vehicle), and $\mathrm{PGE}_{1}$ group (with palate disjunction + prostaglandin administration). Rabbits were fed with a balanced $\operatorname{diet}\left(\mathrm{Ca}, 1.2 \%\right.$; P, 0.8\%; Vitamin $\mathrm{D}_{3}, 1 \mathrm{lU} / \mathrm{g}$ ) and deionized distilled water ad libitum. Control and sham groups received $1 \mathrm{ml} /$ day of vehicle $(0.990 \mathrm{ml}$ saline solution $+0.01 \mathrm{ml}$ ethanol) intravenously for 22 days. The PGE group received $50 \mu \mathrm{g} / \mathrm{ml}$ of $P \mathrm{PE}_{1}$ dissolved in $1 \mathrm{ml}$ of vehicle solution intravenously for 22 days. The $P G E_{1}$ dose was calculated considering an $8 \%$ of lung inactivation $^{8}$. Under pentobarbital sedation, basal X-rays from palatine suture were taken on days 1,3 , and 22 using radiologic plates at $0.08 \mathrm{mAmp} / 65 \mathrm{kV}$. The palatine suture was measured with a millimeter rack. After the basal X-ray, tensional palate disjunction was obtained with a metallic handle orthodontic fixer placed between the rabbits' incisive teeth in the sham and $\mathrm{PGE}_{1}$ groups, with a pressure of $170 \mathrm{~g} / \mathrm{cm}^{2}$. On day 6 , the disjunction was fixed with a steel bar placed under the incisive teeth and a high curing resin, and the orthodontic handle fixer was retired. Since day 6 , all rabbits received an intramuscular dose $(40 \mathrm{mg})$ of oxytetracycline every $12 \mathrm{~h} / 2$ days. Ten days later, oxytetracycline administration was repeated.

On day 22, rabbits were sacrificed under deep general anesthesia. A last X-ray palatine suture and urine sample by bladder puncture were obtained to measure $\mathrm{Ca}, \mathrm{P}$, and cross-linked N-telopeptide ${ }^{9,10}$. Blood samples from the aorta were also collected to measure total $\mathrm{Ca}$ and $\mathrm{Mg}$ (with atomic absorption flame spectrophotometry) and $\mathrm{P}$ levels (by quantitative phosphomolybdate complex spectrophotometry). Total alkaline phosphatase (AkPh) and its thermolabile bone fraction (AkPhO) were quantified by the modified Guttmann method and its bone isoform by the denaturation method $^{9}$. Furthermore, PTH "intact" molecule $\left(\mathrm{PtH}_{1}\right)$, calcitonin (25 Vitamin D), and calcitriol $\left(1,25(\mathrm{OH})_{2} \mathrm{D}_{3}\right)$ were quantified through radioimmunoassay. Samples of the anterior palatine bone were fixed in $70 \%$ alcohol solution and kept at room temperature. Subsequently, they were dehydrated by increasing ethanol concentrations and embedded undecalcified in methyl methacrylate. With a hard work microtome, $4 \mu \mathrm{g}$ thick sections 


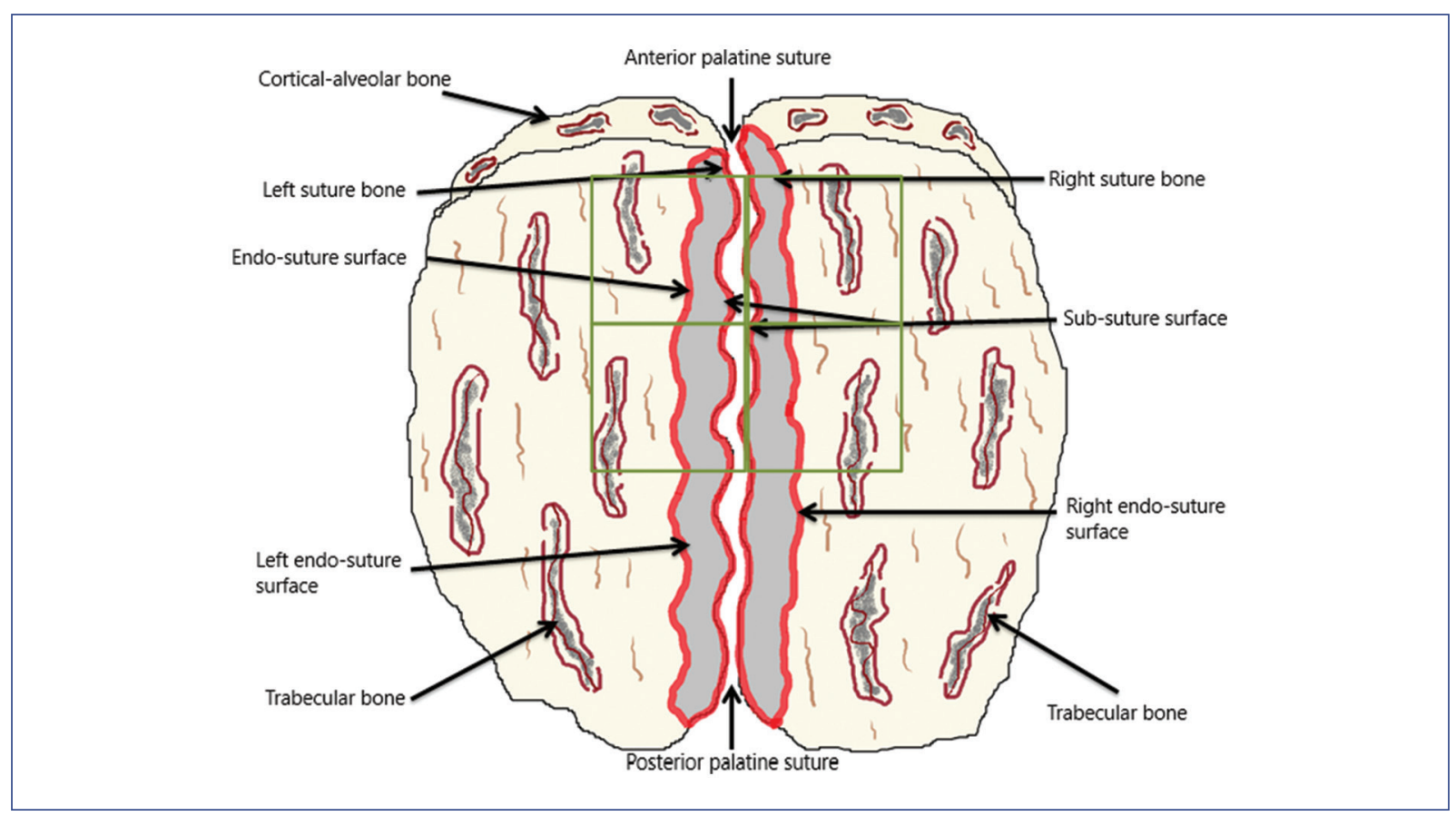

Figure 1. Anatomic diagram of the rabbit's palatine bone with the anterior and posterior regions. The square highlight of the anterior zone shows where the measures were performed; the anatomical identification of the bone surfaces is observed.

were obtained, rehydrated, and stained for MassonGoldner trichrome, toluidine blue, and unstained for fluorescence microscopy. The suture bones (wormian) were measured, starting behind the cortical-alveolar bone towards the posterior region. The anterior, posterior, left, and right bone sutures surfaces and their sub-suture and endo-suture surfaces were identified (Fig. 1). The histomorphometry study of sutural bones was identified as structural, static bone formation, dynamic bone formation, and bone resorption. All analyses were performed using a digitizing table with an osteomeasure software (Osteometrics, Atlanta GA), following the nomenclature and recommendation of the American Society for Bone and Mineral Research ${ }^{11-14}$.

The histomorphometry structural sutural-bone parameters (Sb): bone width (SBwi), bone area (SbAr), bone thickness (SbTh), and sutural bone volume (SbV/TV) were measured in the different groups.

The histomorphometry static bone formation parameters evaluated were osteoid thickness (SbOTh), osteoid surface/bone surface (SbOS/BS), osteoid volume/ bone volume (SbOV/BV), and osteoblasts surface/BS (SbObS/BS). Other static parameters of bone formation were measured to analyze the sutural bone mineralization front (SbMF) in slides stained with toluidine blue, observing the architecture of the cement lines ${ }^{15}$. The
RBF was detected as cement lines scalloped due to prior osteoclast resorption. The MBF was identified as smooth cement lines as if they were forming on a quiescent $\mathrm{BS}^{14-17}$. This assessment was confirmed using a polarizing filter to highlight the collagen fibers' orientation to reflect the shape of the cement line underling the label with toluidine blue. The RBF and MBF were separately quantified as a percentage of total SbMF surfaces $^{14-16}$. The quiescent surface (SbQS) was measured as the percentage of no RBF and no MBF (not stained with toluidine blue), calculated as Ominsky suggested with $100-M B F+R B F+E S / B S^{16}$. The histomorphometry dynamic parameters of bone formation measure the mineralizing surface/BS (SbMS/BS); the mineral apposition rate (SbMAR); the osteoid maturation time (Omt); the mineralization lag time (MLT), and the bone formation rate/BS (SbBFR/BS). Resorption histomorphometry bone parameters (sutural bone osteoclast surface/BS [SbOcS/BS] and sutural bone eroded surface/BS [SbES/BS]) were quantified as well ${ }^{11,13,14}$.

These histomorphometric studies were validated with the previously mentioned software comparing control versus $P_{G E}$ groups. The means and standard deviations were calculated in each subgroup. Parameter differences were tested with the Student's t-test and the 
Table 1. Radiologic results of palate disjunction and teeth separation

\begin{tabular}{|l|l|c|c|c|c|}
\hline Radiological results & Date & Control group & Sham group & PGE $_{\mathbf{1}}$ group & p-values (sham vs. PGE $)$ \\
\hline $\begin{array}{l}\text { X-ray 1 } \\
\text { Disjunction (mm) }\end{array}$ & Basal & $0.07 \pm 0.006$ & $0.09 \pm 0.01$ & $0.08 \pm 0.009$ & 0.1 \\
& Day 3 & $0.09 \pm 0.01$ & $0.29 \pm 0.05$ & $0.37 \pm 0.09$ & $0.05^{*}$ \\
\hline & Day 22 & $0.09 \pm 0.01$ & $0.25 \pm 0.04$ & $0.24 \pm 0.07$ & 0.1 \\
\hline $\begin{array}{l}\text { X-ray 2 } \\
\text { Teeth separation (mm) }\end{array}$ & Basal & 0 & 0 & 0 & - \\
\hline & Day 3 & 0 & $4.6 \pm 0.56$ & $4.65 \pm 0.45$ & 0.1 \\
\hline
\end{tabular}

${ }^{*} \mathrm{p}<0.05 ;{ }^{* *} \mathrm{p}<0.01$

$P E_{1}$ : prostaglandin $E_{1}$.

Table 2. Blood and urine bone formation markers on day 22 in rabbits with palate bone disjunction treated with $\mathrm{PGE}_{1}$

\begin{tabular}{|c|c|c|c|c|}
\hline Variables & Control group & Sham group & PGE $_{1}$ group & p-values (sham vs. PGE $_{1}$ ) \\
\hline $\mathrm{Ca}(\mathrm{mg} / \mathrm{dL})$ & $11.55 \pm 0.72$ & $11.55 \pm 0.68$ & $11.85 \pm 0.42$ & 0.1 \\
\hline $\mathrm{Mg}(\mathrm{mg} / \mathrm{dL})$ & $2.40 \pm 0.27$ & $2.01 \pm 0.54$ & $2.20 \pm 0.20$ & 0.1 \\
\hline$P(m g / d L)$ & $5.17 \pm 0.65$ & $5.03 \pm 0.43$ & $5.26 \pm 0.14$ & 0.1 \\
\hline AkPh (IU/L) & $73.35 \pm 24.3$ & $67.37 \pm 17.0$ & $61.37 \pm 11.2$ & 0.1 \\
\hline Bone AkPh0 (\%) & $53.12 \pm 10.5$ & $56.50 \pm 9.38$ & $50.00 \pm 16.2$ & 0.1 \\
\hline Vitamin $\mathrm{D}_{3}(\mathrm{ng} / \mathrm{mL})$ & $38.16 \pm 15.7$ & $47.0 \pm 20.6$ & $39.0 \pm 18.7$ & 0.1 \\
\hline PTHi (pg/mL) & $28.1 \pm 15.6$ & $30.2 \pm 26.0$ & $27.4 \pm 10.1$ & 0.1 \\
\hline Calcitonin $(\mathrm{pg} / \mathrm{mL})$ & $32.3 \pm 11.3$ & $40.1 \pm 20.5$ & $28.4 \pm 15.1$ & 0.1 \\
\hline Calcitriol (pg/mL) & $50.5 \pm 13.15$ & $48.0 \pm 13.8$ & $82.1 \pm 13.5$ & $0.002^{* *}$ \\
\hline \multicolumn{5}{|c|}{ Urine bone formation markers on day 22} \\
\hline $\mathrm{Ca}(\mathrm{mg} / \mathrm{dL})$ & $186 \pm 665$ & $178 \pm 53.3^{*}$ & $376 \pm 102.2$ & $0.001^{*}$ \\
\hline$P(\mathrm{mg} / \mathrm{dL})$ & $28 \pm 5.3$ & $29 \pm 14.1$ & $42 \pm 21.6$ & 0.1 \\
\hline N-telopeptide (nMBCE) & $32 \pm 4.1$ & $38 \pm 16.5$ & $30 \pm 2.0$ & 0.1 \\
\hline
\end{tabular}

${ }^{*} \mathrm{p}<0.001 ; * * \mathrm{p}<0.002$.

AkPh: total alkaline phosphatase; AkPhO: alkaline phosphatase thermolabile bone fraction; $\mathrm{PGE}_{1}$ : prostaglandin E1; PTHi: intact parathyroid hormone.

Fisher test (with a significant value of $<5 \%$ ). All results were analyzed with the SPSS V-18 software.

\section{Results}

Palate bone disjunction and in vivo radiological results are shown in table 1 . On day 3 , we observed a significant difference of palatine suture width $(p<0.05)$ between the sham and $\mathrm{PGE}_{1}$ groups. On day 22, a significant teeth separation $(p<0.01)$ was detected between these groups.
Blood levels of $\mathrm{Ca}, \mathrm{Mg}$, and $\mathrm{P}$ were similar between groups. The absence of hypercalcemia in the $\mathrm{PGE}_{1}$ group was noticeable (Table 2). No significant differences were observed in biochemical markers concentration, except for calcitriol in the $\mathrm{PGE}_{1}$ group, which was significantly higher than the sham group $(p<0.002)$.

Urine $\mathrm{Ca}$ levels group were significantly high $(p<0.001)$ in the $P G E_{1}$, but the phosphaturia and the cross-linked N-telopeptide of type 1 collagen were similar in all groups. Interestingly, the biochemical marker 
of bone resorption (N-telopeptide) was not increased in the $\mathrm{PGE}_{1}$ group (Table 2).

The structural histomorphometry parameters of the sutural bone in the $\mathrm{PGE}_{1}$ group exhibited anabolic bone formation evidenced by significant increases in the $\operatorname{SbAr}(p=0.014)$, SbTh $(p<0.001)$, and SbV $(p=0.007)$ compared with the sham group (Fig. 2). In the $\mathrm{PGE}_{1}$ group, the static bone formation parameters showed a significant decrease in osteoid thickness, sutural bone osteoid surface, and sutural bone osteoid volume/BV (Table 3). The number of sutural bone osteoclast surface/BS was similar in all groups.

In the sham group, we observed $19.7 \%$ of SbRBF but only $5.9 \%$ of SbMBF. On the contrary, in the $\mathrm{PGE}_{1}$ group, we observed $8.6 \%$ of SbRBF and $16.6 \%$ of SBMBF (Table 3).

Under polarized light, we corroborated the irregular lamellar lines of RBF and the regular lamellar lines of SbMBF (Fig. 3). The sutural surface of quiescent bone areas was similar between the sham and $\mathrm{PGE}_{1}$ groups (Table 3).

Dynamic histomorphometry parameters of sutural bone formation showed differences in mineralizing bone markers. When comparing the control group versus the PGE1 group, we observed a significant shortening of Omt $(p=0.009)$ and mineralizing lag time ( $p$ $<0.001$ ) (Table 3). The SbBFR/BS activity were similar between the sham and $P G E_{1}$ groups but higher than the control group. With Masson-Goldner trichrome stain, no significant differences were observed in the static histomorphometry resorption parameters of the sutural bone between groups (Table 3 ).

\section{Discussion}

The present study demonstrated that $P \mathrm{PE}_{1}$ treatment produced a wider palate disjunction with fast anabolic sutural bone formation, significant reduction of the mineralizing time, and slight bone resorption, resulting in histomorphometry increased BV mainly through modeling-formation with no hypercalcemia. Significant increases in bone mineral volume and fracture risk reduction have generated much enthusiasm for using anabolic therapy in osteoporotic patients.

In the present study, the anabolic impact of $\mathrm{PGE}_{1}$ administration on the palatine-bones was confirmed by biochemical and histomorphometry findings. $P \mathrm{PE}_{1}$ increased significantly the synthesis of $1,25(\mathrm{OH})_{2} \mathrm{D}_{3}$ $(p<0.002)$ compared to the control and sham groups but did not produce hypercalcemia, even though hypercalciuria $(p<0.001)$ was detected in rabbits that

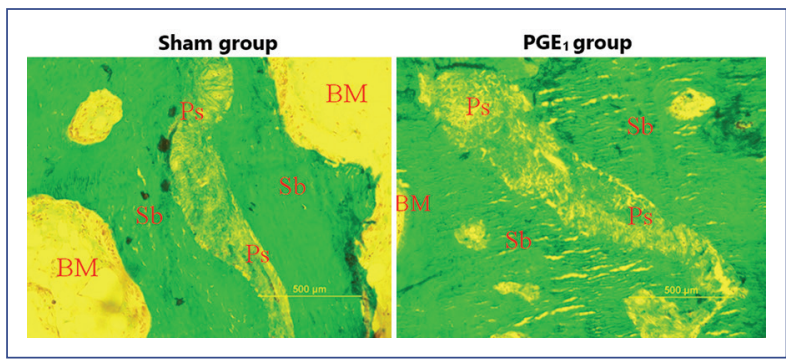

Figure 2. Comparing the sutural bone volume/tissue volume from the sham group versus the prostaglandin $E_{1}\left(P_{1} E_{1}\right)$ group. On the sagittal sections with the same magnification for both images, we observed a significant anabolic increase of the sutural bone (right) in the PGE group ( $p=0.007)$. Ps: palatine suture; Sb: suture bone; BM: bone marrow. Stained with Goldner's trichrome, $10.0 \mathrm{~mm} \times 12.5 \mathrm{~mm}$ objective.

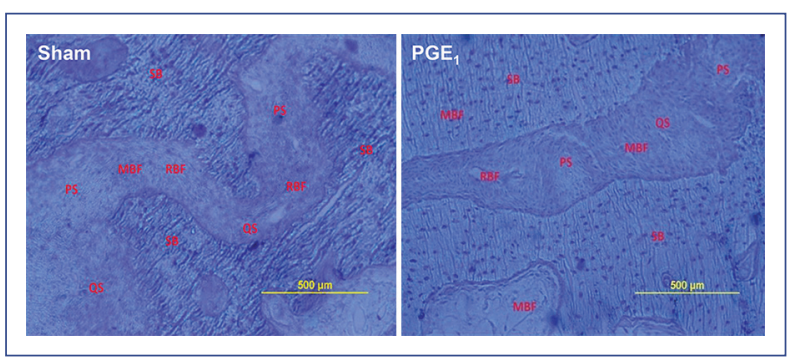

Figure 3. Mineralization front of the sutural bone was identified with a toluidine blue stain. In the sham group (no prostaglandin $E_{1}\left[P_{G} E_{1}\right]$ ), the scalloped cement lines predominated (remodeling-based bone formation). In contrast, in the $\mathrm{PGE}_{1}$ group, the smooth cement lines predominated (modeling-based bone formation). MBF: modeling bone formation; PS: palatine suture; OS: quiescent surface; RBF: remodeling bone formation; $\mathrm{SB}$ : suture bone. Toluidine blue stain, $10.0 \mathrm{~mm} \times 12.5 \mathrm{~mm}$ objective.

received $\mathrm{PGE}_{1}$ (Table 2). We previously observed this phenomenon in vivo in rabbits and in vitro ${ }^{5}$. The resorption markers ( $\mathrm{N}$-telopeptide levels) remained similar due to an apparent low $\mathrm{PGE}_{1}$ resorption (Table 2).

The histomorphometry study on the sutural bones exhibited a significant anabolic growth characterized by a significant increase of the sutural area $(p<0.01)$, sutural thickness $(p<0.001)$, and the SbV $(p=0.007)$ compared with the sham group ${ }^{16,18}$.

When comparing the histomorphometry parameters between the sham and $P G E_{1}$ groups, we found that bone formation was reversed. The RBF in the sham group was significantly higher $(\mathrm{SbRBF}=19.7 \%)$ when 
Table 3. Structural histomorphometry parameters of the sutural bone

\begin{tabular}{|c|c|c|c|c|}
\hline Variable & Control group & Sham group & $\mathrm{PGE}_{1}$ group & p-values (sham vs. $\mathrm{PGE}_{1}$ ) \\
\hline SbWi $(\mu \mathrm{m})$ & $125.36 \pm 38.79$ & $201.32 \pm 96.91$ & $260.08 \pm 66.85$ & 0.1 \\
\hline $\operatorname{SbAr}\left(\mathrm{mm}^{2}\right)$ & $0.29 \pm 0.12$ & $0.36 \pm 0.09$ & $0.53 \pm 0.08$ & $0.014^{*}$ \\
\hline $\operatorname{SbTh}(\mu \mathrm{m})$ & $452.47 \pm 86.14$ & $810.03 \pm 373.8$ & $1007.8 \pm 246.4^{*}$ & $0.001^{* *}$ \\
\hline SbV/TV (\%) & $35.62 \pm 11.1$ & $42.23 \pm 11.25$ & $57.20 \pm 8.12$ & $0.007^{*}$ \\
\hline \multicolumn{5}{|c|}{ Static histomorphometry parameters of sutural bone formation } \\
\hline SbOTh $(\mu \mathrm{m})$ & $14.05 \pm 1.85$ & $13.65 \pm 2.02$ & $7.98 \pm 2.79$ & $0.004^{*}$ \\
\hline SbOS/BS (\%) & $38.35 \pm 10.04$ & $20.12 \pm 7.56$ & $8.71 \pm 5.10$ & $0.01^{*}$ \\
\hline SbOV/BV $(\%)$ & $0.45 \pm 0.27$ & $0.67 \pm 0.36$ & $0.26 \pm 2.26$ & $0.007^{*}$ \\
\hline SbObS/BS (\%) & $18.62 \pm 8.01$ & $19 \pm 6.45$ & $15.45 \pm 2.60$ & 0.345 \\
\hline $\operatorname{SbRBF}(\%)$ & $13.81 \pm 2.85$ & $19.7 \pm 6.12$ & $8.64 \pm 1.34$ & $0.001^{* *}$ \\
\hline $\operatorname{SbMBF}(\%)$ & $3.36 \pm 0.74$ & $5.98 \pm 2.53$ & $16.68 \pm 4.42$ & $0.001^{* *}$ \\
\hline SbOS $(\%)$ & $81.53 \pm 2.96$ & $72.96 \pm 7.92$ & $73.84 \pm 4.44$ & 0.293 \\
\hline \multicolumn{5}{|c|}{ Dynamic histomorphometry parameters of sutural bone formation } \\
\hline SbMS/BS $(\%)$ & $67.671 \pm 13.56$ & $281.85 \pm 56.37$ & $273.07 \pm 54.61$ & 0.1 \\
\hline $\operatorname{SbMAR}(\mu \mathrm{m} / \mathrm{day})$ & $2.85 \pm 0.49$ & $4.73 \pm 1.13$ & $4.81 \pm 0.77$ & 0.983 \\
\hline Omt (days) & $5.11 \pm 1.35$ & $3.00 \pm 0.69$ & $1.72 \pm 0.77$ & $0.009 *$ \\
\hline MLT (days) & $23.30 \pm 4.03$ & $22.21 \pm 3.18$ & $10.38 \pm 2.95$ & $0.001^{* *}$ \\
\hline $\operatorname{SbBFR/BS~}\left(\mu \mathrm{m}^{3} / \mu \mathrm{m}^{2} / \mathrm{year}\right)$ & $703.94 \pm 140.78$ & $4865.99 \pm 973.19$ & $4794.15 \pm 958.33$ & 0.1 \\
\hline \multicolumn{5}{|c|}{ Static histomorphometry parameters of sutural bone resorption } \\
\hline Sb0cS/BS $(\%)$ & $1.12 \pm 0.52$ & $1.34 \pm 0.98$ & $0.87 \pm 0.38$ & 0.1 \\
\hline SbES/BS (\%) & $3.63 \pm 1.44$ & $4.04 \pm 3.15$ & $3.18 \pm 1.62$ & 0.1 \\
\hline
\end{tabular}

${ }^{*} \mathrm{p}<0.05 ;{ }^{* *} \mathrm{p}<0.001$.

$\mathrm{PGE}_{1}$ : prostaglandin $\mathrm{E}_{1}$; SbWi: sutural bone width; SbAr: sutural bone area; SbTh: sutural bone thickness; SbV/TV: sutural bone volume/tissue volume; SbOTh: sutural bone osteoid thickness; SbOS/BS: sutural bone osteoid surface/bone surface; SbOV/BV: sutural bone osteoid volume/bone volume; SbObS/BS: sutural bone osteoblast surface/ bone surface; SbRBF: sutural bone remodeling bone formation; SbMBF: sutural bone modeling bone formation; SbOS: sutural bone quiescent surface; SbMS/BS: sutural bone mineralizing surface/bone surface; SbMAR: sutural bone mineral apposition rate; Omt: osteoid maturation time; MLT: mineralization lag time; SbBFR/BS: sutural bone formation activity/bone surface; SbOcS/BS: sutural bone osteoclast surface/bone surface; SbES/BS: sutural bone eroded surface/bone surface.

compared with the MBF of the same group (SbMF = $5.9 \%)$. In the $\mathrm{PGE}_{1}$ group, the histomorphometry bone formation values were contrasting because the MBF was high (SbMF $=16.7 \%)$, and apparently, $\mathrm{PGE}_{1}$ inhibited the activation of bone remodeling (SbRBF $=8.6 \%$ ) as reflected in decreased sutural bones resorptive parameters (Table 3). Serum biochemical markers were correlated with the histological findings, as the group that received $\mathrm{PGE}_{1}$ did not exhibit hypercalcemia. No increased resorption marker ( $\mathrm{N}$-telopeptides) was found in either the control or $\mathrm{PGE}_{1}$ groups (Table 2). These findings suggest that $P G E_{1}$ differs from other anabolic bone agents and is near to be the "ideal bone anabolic molecule" that could optimize the impact on bone formation, producing fewer histomorphometry changes in resorption, and not inducing hypercalcemia ${ }^{3}$.

After Villanueva et al. ${ }^{14}$ identified the MF with toluidine blue staining, Miller and Marks ${ }^{18}$, using fluorochrome technology, observed that after $\mathrm{PGE}_{1}$ administration, periosteal bone formation was not preceded by the resorption phase, indicating that bone anabolism is stimulated mainly by bone modeling ${ }^{19}$.

At present, the only anabolic bone therapies available are the PTH forms: PTH 1-34, PTH 1-86, PTH 1-36, and abaloparatide ${ }^{3,4}$. These therapies have proved to be safe and effective. However, they increase bone resorption and induce hypercalcemia. Horwitz et al. ${ }^{20}$ suggested that PTHr related proteins might increase bone formation in the absence of 
hypercalcemia; slight resorption was also observed. Another exciting area in the exploration of combining PTH therapy with antiresorptive agents has produced intriguing results ${ }^{21,22}$. Some authors used antibodies against inhibitors of bone formation, such as the sclerostin (osteocytes secreted negative regulator of bone formation) ${ }^{16}$, odanacatib (cathepsin $\mathrm{K}$ inhibitor) ${ }^{23}$, and denosumab (a human monoclonal antibody that binds and inhibits RANK ${ }^{24}$, and found that these antibodies favored anabolism and did not produce hypercalcemia. Most of these bone inhibitor antibodies, including PGE , $_{1}$ produced bone anabolism by a mechanism in which the MBF is observed predominately as smooth cement lines. Those changes are significant findings since they may be interpreted as an activation that produces bone anabolism with inadequate bone resorption, usually without hypercalcemia ${ }^{14-16,19}$.

These findings suggest that $P G E_{1}$ treatment could act through an MBF mechanism to achieve anabolism with low resorption and no hypercalcemia in osteopenic diseases. This therapy could be evaluated in clinical research for other diseases, including human maxillary deficiency (a frequent disease in children), osteoporosis in adults, or any osteopenic problem. Our findings may represent new potential information for repairing bone fractures, osteomalacia/rickets, and other osteopenic disorders.

The SbOTh, SbOS/BS, and the SbOS/BV on the PGE1 group were less than the other groups, perhaps due to the acceleration of osteoid mineralization, while the mild increase in the mineral appositional rate is indicative of increased bone production ${ }^{25}$. Regarding the dynamic bone formation parameters, after 22 days of $\mathrm{PGE}_{1}$ treatment, we observed a significant shortening of the time of osteoid mineralization and $\mathrm{MLT}^{26}$. These findings suggest that $\mathrm{PGE}_{1}$ accelerates bone matrix mineralization, decreasing the osteoid sutural BS and increasing bone anabolism.

Understanding the effects of $\mathrm{PGE}_{1}$ on bone modeling and remodeling might help clarify its effects on bone formation and evaluate bone increase. We observed the same percentage of RBF and MBF in healthy children in iliac crest biopsies of the trabecular bone tissues ${ }^{15}$.

The effect of $\mathrm{PGE}_{1}$ on MBF has not yet been demonstrated in human adults. However, the biomarker's profile and histomorphometry results in children and animal models are encouraging ${ }^{14,16,25}$. We should further compare the MF identification with staining techniques, like tetracycline chelation.
In conclusion, the exogenous $\mathrm{PGE}_{1}$ treatment in rabbits exhibited a wider suture palate disjunction, increased calcitriol synthesis, and the sutural palatine bones volume, and shortened MLT. The bone anabolic effect may be exerted mainly through MBF, producing mild resorption without hypercalcemia. These findings could lead to new potential options for osteopenia treatments.

\section{Ethical disclosures}

Protection of human and animal subjects. The authors declare that the procedures followed the regulations of the relevant clinical research ethics committee and those of the Code of Ethics of the World Medical Association (Declaration of Helsinki).

Confidentiality of data. The authors declare that they have followed the protocols of their work center on patient data publication.

Right to privacy and informed consent. The authors declare that no patient data appear in this article.

\section{Conflicts of interest}

The authors declare no conflict of interest.

\section{Funding}

Federal funds: HIM/2015/001 SSA. 1192.

\section{Acknowledgments}

The authors wish to thank Raquel Jiménez Aguilar ${ }^{\dagger}$ for her histotechnological assistance, Sandra Luz Olivas Gómez for her secretarial assistance, and the animal facilities workers at the Hospital Infantil de México Federico Gómez for their collaboration.

\section{References}

1. Kraemer S, Meade E, De Witt D. Prostaglandin endoperoxide synthase gene structure: identification of the transcriptional start site and 5'-flanking regulatory sequences. Arch Biochem Biophys. 1992;293:391-400.

2. Narumiya S, Sugimoto Y, Ushikubi F. Prostanoid receptors: structures, properties and functions. Physiol Rev. 1999;79:1193-226.

3. Black D, Schafer A. The search for the optimal anabolic osteoporosis therapy. J Bone Miner Res. 2013;28:2263-5.

4. Martin J, Seeman E. Abaloparatide is an anabolic, but does it spare resorption? J Bone Miner Res. 2017;32:11-6.

5. Velásquez-Forero F, García P, Triffit J, Llach F. Prostaglandin E1 increases in vivo and in vitro calcitriol biosynthesis in rabbits. Prostaglandins Leukot Essent Fatty Acids. 2006;75:107-15.

6. Johnson PD, Besselsen DG. Practical aspects of experimental design in animal research. ILAR J. 2002;43:202-6.

7. Secretaría de Agricultura, Ganadería, Desarrollo Rural, Pesca y Alimentación. NORMA Oficial Mexicana NOM-062-ZOO-1999. Especificaciones Técnicas Para la Producción, Cuidado y uso de los Animales de Laboratorio. 
8. Golub M, Zia P, Matsuno M, Horton R. Metabolism of prostaglandins A1 and $\mathrm{E} 1$ in man. J Clin Invest. 1975;56:1404-10.

9. Calvo MS, Eyre DR, Gundberg CM. Molecular basis and clinical application of biological markers of bone turnover. Endoc Rev. 1996;17:333-68.

10. Hanson D, Weis M, Bollen A, Maslan S, Singer F, Eyre D. A specific immunoassay for monitoring human bone resorption: quantitation of type I collagen cross-linked N-telopeptides in urine. J Bone Miner Res. 1992;7:1251-8.

11. Dempster D, Compston J, Drezner M, Glorieux F, Kanis J, Malluche H, et al. Standardized nomenclature, symbols and units for bone histomorphometry: a 2012 update of the report of the ASBMR Histomorphometry Nomenclature Committee. J Bone Miner Res. 2013;28:2-17.

12. Rauch F. Watching bone cells at work: what we can see from bone biopsies. Pediatr Nephrol. 2006;21:457-62.

13. Glorieux F, Travers R, Taylor A, Bowen J, Rauch F, Norman M, et at. Normative data for iliac bone histomorphometry in growing children. Bone. 2000;26:103-9.

14. Villanueva A, Kujawa M, Mathews C, Parfitt A. Identification of the mineralization front: comparison of a modified toluidine blue stain with tetracycline fluorescence. Meta Bone Dis Relat Res. 1983;5:41-5

15. Velásquez-Forero F, Jiménez-Brau D, Esparza-García M. Histomorphometric reference data of transiliac bone biopsy in children from 8 to 17 years old. Bol Med Hosp Infant Mex. 2018;75:135-44.

16. Ominsky M, Niu Q, Li C, Li X, Zhu K. Tissue-level mechanisms responsible for the increase in bone formation and bone volume by sclerostin antibody. J Bone Miner Res. 2014;29:1424-30.

17. Frost $\mathrm{H}$. Tetracycline-based histological analysis of bone remodeling. Calcified Tissue Int. 1969;3:211-37.

18. Miller S, Marks S. Local stimulation of new bone formation by prostaglandin E1: quantitative histomorphometry and comparison of delivery by minipumps and controlled-release pellets. Bone. 1993;14:143-51.
19. Erben R. Trabecular and endocortical bone surfaces in the rat: modelling or remodelling? Anat Rec. 1996;246:39-46.

20. Horwitz M, Augustine A, Kahn L, Martin E, Oakley C, Carneiro R, et al. A comparison of parathyroid hormone-related protein (1-36) and parathyroid hormone (1-34) on markers of bone turnover and bone density in postmenopausal women: the PrOP study. J Bone Miner Res. 2013;28:2266-76

21. Deal C, Omizo M, Schwartz E, Eriksen E, Cantor P, Wang J, et al. Combination teriparatide and raloxifene therapy for postmenopausal osteoporosis: results from a 6-month double-blind placebo-controlled trial. J Bone Miner Res. 2005;20:1905-11.

22. Cosman F, Eriksen E, Recknor C, Miller P, Guañabens N, Kasperk C, et al. Effects of intravenous zoledronic acid plus subcutaneous teriparatide $[(1-34) \mathrm{rhPTH}]$ in postmenopausal osteoporosis. J. Bone Miner Res. 2011;26:503-11.

23. Brixen K, Chapurlat R, Cheung A, Keaveny T, Fuerst $T$, Engelke $\mathrm{K}$, et al. Bone density, turnover, and estimated strength in postmenopausal women treated with odanacatib: a randomized trial. J Clin Endocrinol Metab. 2013:98:571-80

24. Tsai J, Uihlein A, Lee H, Kumbhani R, Siwila-Sackman E, McKay E, et al. Teriparatide and denosumab alone or combined in women with postmenopausal osteoporosis: the DATA study randomised trial. Lancet. 2013;382:50-6.

25. High W. Effect of orally administered prostaglandin E-2 on cortical bone turnover in adult dogs: a histomorphometric study. Bone. 1987;8:363-73.

26. Velásquez F, Morales M, Sierra C, Socias F, Ito J. The Prostaglandin E1 Shortens the Mineralization Lag Time in Cat's Palatine Bone Disjunction. Histomorphometric Bone Study. Kansas City, Missouri, USA: American Society for Bone and Mineral Research, $16^{\text {th }}$ Annual Meeting; 1994. 